\title{
Cezayirli Ailelerde Çocuğa Yönelik İslami Eğitimin Yöntem ve Amaçları*
}

\author{
CEVIDA EMIRA [DJAOUIDA AMIRA] \\ MUSTAFA MÜCAHIT
}

\section{Özet}

Allah'ın anne ve babalara verdiği nimetlerden biri olan çocuklar, onlara mutluluk ve geleceklerinin garantisi duygularını vermektedir. Bu nimete karşı da ebeveynlerin onlara karşı, aile içinde pek çok sorumlukları vardır. Bu sorumluluklardan biri de Yüce Allah'ın emrettiği şekilde çocukların dinî bakımdan yetiştirilmesidir.

Ailede İslami eğitim, dinin ve hayatın tüm yönlerini kapsayacak şekilde yapılmalıdır. İslam dini inanç, ibadet, ahlak ve muamelat olmak üzere dört ögeden oluşur. Bu nedenle Müslüman ebeveynler çocuklarını bu alanlarda eğiterek, onların dinî kişiliklerini kazanmalarını isterler.

Müslümanlar, çocukla ve onun eğitimiyle çok ilgilenmiştir, çünkü çocukluk dönemi bir Müslüman'ın kişiliğini inşa etmenin temel aşamasıdır. Bu makale Cezayirli çocuklara, aileleri tarafından nasıl bir din eğitimi verildiğini ortaya koymayı amaçlamaktadır. Bu amaçla, hangi yaşta, hangi konular, hangi yöntemlerle öğretilmektedir konuları tartışılmıştır. Bir alan araştırması olan bu çalışma nicel bir çalışmadır. Araştırmanın verileri, Nisan 2015'te Cezayir'de

* Bu makale Cevida Emira tarafından Arapça olarak yazılmış, Mustafa Mücahit tarafından Türkçeye çevrilmiştir.

- ARASTIRMA MAKALESI-

CEVIDA EMIRA (DJAOUIDA AMIRA), amiratdj@gmail.com Cezayir 2 Üniversitesi Sosyal Bilimler Fakültesi ORCiD https://orcid.org/0000-0001-8378-2295

MUSTAFA MÜCAHIT, mmucahit@hotmail.com Sivas Cumhuriyet Üniversitesi Illahiyat Fakültesi ORCiD https://orcid.org/0000-0003-2345-0015

Gelis tarihi: 29.09.2021 • Kabul tarihi: 31.10.2021 doi: https://doi.org/10.47646/CMD.2021.252 
yaşayan ve en az bir çocuğu üç yaşından büyük 385 anne babaya uygulanan anketten elde edilmiştir. Bulgular tablolarda verilmiş ve yorumlanmıştır.

Anahtar kelimeler: Çocuk, İslami terbiye, İslami eğitim, din eğitimi, Cezayirli çocuklar, Cezayirli anne babalar.

\section{Abstract}

Children, one of God's blessings to parents, give them feelings of happiness and the guarantee of their future. Against this blessing, parents have many responsibilities towards them within the family. One of these responsibilities is the religious upbringing of children as commanded by Allah Almighty.

Islamic education in the family should be done in a way that covers all aspects of religion and life. The religion of Islam consists of four elements: belief, worship, morality and treatment. This is the reason why Muslim parents want their children to gain their religious personality by educating them in these areas.

Muslims have been very interested in children and their education, because childhood is the basic stage in building a Muslim's personality. This article aims to reveal what kind of religious education is given to Algerian children by their families. For this purpose are discussed which subjects are taught with which methods and at which age. This field study is a quantitative study. The data of the study was obtained from a questionnaire applied to 385 parents living in Algeria and having at least one child older than three years old in April 2015. Findings are given in tables and interpreted.

Keywords: Child, Islamic upbringing, Islamic education, Religious education, Algerian children, Algerian parents

\section{Arapça Özet}

\section{أساليب وأهداف التربية الاسلامية للطفل في الأسرة الجزائرية}

أ. أد عميرة جويدة

مترجمة: مجا مد مصطفد
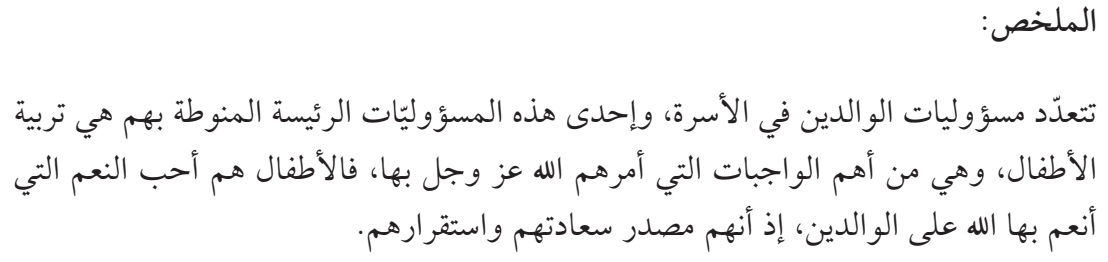


$$
\begin{aligned}
& \text { وتمتاز التربية الإسلامية في الأسرة بالشمول والتكامل مع جميع نواحي الحياة لأنها منهج حياة } \\
& \text { المسلم. } \\
& \text { فلقد اهتم الدين الإسلامي بالطفل واعتنى به عنايةً فائقةً، لان مرحلة الطفولة هي المرحلة } \\
& \text { الأساسية في بناء شخصية المسلم، حيث أوجب الإسلام على الو الدين توجيه أطفالهم توجيهًا }
\end{aligned}
$$

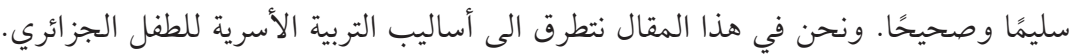

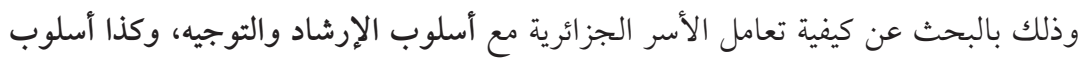

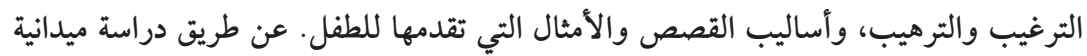

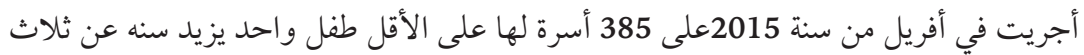

$$
\begin{aligned}
& \text { سنوات وتقطن بالجزائر العاصمة. } \\
& \text { الكلمات المفتاحية: } \\
& \text { الطفل، التربية الإسلامية، الأخلاق، الايمان، أسلوب الإرشاد والتوجيه، أسلوب القدوة } \\
& \text { الصالحة، أسلوب الترغيب والترهيب، أسلوب القصطُ والأمثال. }
\end{aligned}
$$

\section{Giriş}

Dünyaya bir şey bilmeden gelen çocukların, sosyal hayata uyum sağlamaları, disiplinli ve kararlı bir ahlaki bir kişiliğe sahip olmaları için bir eğitime ihtiyaçları olduğu açıtır. Çocuğun ilk eğitimi ailesi tarafından verilir. Çocukluk döneminde alınan eğitim, çocuğun kişiliği üzerinde oldukça etkilidir. Bu nedenle anne babaların bilinçli davranışlarıyla, onlar, gelecekte güçlü, düşünen ve üretken bir toplum inşa etmede güçlü yapı taşları hâline gelirler. Böyle bir eğitim ve ahlak, ancak bunun için kurallar koyan İslam dininin ilkelerinden kaynaklanmaktadır.

İslam, ilkeleri ve hukukuyla insanı, Rabbani (ilahî) bir terbiyeden geçirmeyi planlar. Bunu yaparken, insanın doğru, temiz ve sağlıklı bir hayat yaşayabilmesi için, doğuştan getirdiği özelliklerinin bir bütün olarak ele alınması gerektiğini kabul etmesinin yanında, iyi insan olmayı, inanç amel birlikteliğine bağlamıştır. İslam eğitiminin esasları çerçevesinde yetişen insan, takva derecesine ulaşır ve ilmin yol göstericiliği ışı̆̆ında kendi mutluluğu yanında toplum ile de uyumlu bir hayat yaşamış olur. Çünkü İslam, aile çevresinde ve genel anlamıyla da toplumda çocukların hak ettikleri şekilde yetiştirilmesi ve gözetilmesiyle ilgili hedefler koymuştur. Bu yüksek hedeflere ulaşmak için Kur'an-1 Kerim, imanla salih ameli her zaman birlikte dile getirir. "Iman edip de iyi davranışlarda bulunanlar bilmelidirler ki 
biz, güzel iş yapanların ödülünü vermemezlik etmeyiz."

Çocuk, İslam dini tarafindan kabul edildiği gibi, günümüzde de Birleşmiş Milletlerin belgelerinde bütün hakları belirlenmiş bir insan olarak kabul edilmektedir. ${ }^{2}$ Çocuk haklarından birisi de doğmuş olduğu çevrede "kimliğini ve dinini" kazanma hakkıdır. Bu nedenle bireyleri ve toplumu yönlendiren o çevrede geçerli kültürel ve dinî anlayışa bağlı olarak çocuğun eğitiminin toplumdan topluma farklılık gösterdiği görülebilmektedir. Bununla bağlantılı olarak çocukla iletişim yöntemleri de onun yaşadığı kültürel ortama göre değişebilmektedir. Bilindiği gibi herhangi bir toplumun dinî inancından kaynaklanan ahlaki değerleri, davranışları ve zevkleri, düşünce, bilim, edebiyat ve sanat alanında bireylerinin ortaya koydukları seçkin özellikleri o toplumun kültürünü oluşturmaktadır.

\section{Problem ve Hipotezler/Denenceler}

Çağımızda, çocuk eğitiminden ve öneminden söz etmek, entelektüel bir lüks gibi görülmemekte, tam tersi, toplumsal hayatın zorunluluklarından birisini dile getirmektedir. İşte bu bağlamda Bu makalede, Cezayir ailesinde çocuklara din eğitiminde kullanılan yöntem ve amaçlar tartışılmıştır.

İslam eğitimi, insanı sadece Allah'a kul yapmayı, ona hiçbir şeyi ortak koşmamayı hedefler. Kişi onun rızası ve emirleri çerçevesinde davranmalıdır. Kuşkusuz bir kusur işlediğinde hemen O'na tövbe etmesi ve yalvarması gerekir. Buna göre eğitim, Kur'ani bir ahlak ve nebevî bir terbiye üzerine kurulur. İslam eğitimi, kardeşlik ve yardımlaşma, iyilik ve takva, merhamet ve hoşgörü vb. güzel ahlak sahibi insanların yetiştirilmesi için, vahyin ve aklın yol göstericiliğinde oluşmuş bir eğitimdir.

Yüce Allah'ın razı olduğu iyi bir kul olabilmek için yapılması gereken davranışlar Kur'an-ı Kerim'deki Rabbanî ölçülerle belirlenmiştir. Bu nedenle eğitim, inananları sadece Allah'a kulluk etmeye yönelik olmalıdır. İnanan bir kimse yüce yaratıcısına gerçek bir kulluk sergilediğinde, mütevazı bir insan olacak, Allah'ın cömertçe verdiği nimetlere razı olacak, kendisi için asıl mutluluğun ve ödülün ahirette olacağına inanacaktır. Bu samimi yaklaşım ona güç katacaktır. Çünkü o sadece Allah rızası için hareket edecek ve hatta erdemli davranışları elde etme ve onları yayma noktasında O'nun hoşnutluğundan başka bir şey için çabalamayacaktır.

1 Kehf 18/30.

2 Özellikle 20 Kasım 1959 tarihli Birleşmiş Milletler Çocuk Hakları Bildirgesi bu konuyu ayrıntılı olarak açıklamıştır. 
Teorik olarak, İslam'ın bakış açısı böyledir. Ancak çoğunluğu Müslüman olan Cezayir ailelerinde çocuk eğitiminin bu esaslara uygun olarak yapılıp yapılmadığı araştırmaya muhtaçtır. Bu çalışmada, Cezayirli çocukların aileleri tarafından nasıl eğitildikleri ve özellikle ahlaki erdemlerin nasıl verildiği ve hedeflerinin ne olduğu araştırılmıştır. Bu çerçevede şu sorulara cevap aranmıştır:

Cezayirli aileler, çocukları yönlendirme ve onlara yol göstermede nasıl bir davranış içindedirler?

Cezayirli aileler, çocuklarına din öğretiminde dinin hangi konuları tercih etmektedirler?

Cezayirli aileler özendirme ve sakındırma konusunda nasıl davranmaktadırlar?

Cezayirli ailelerin kullandıkları hikâye ve örneklendirme yöntemleri nelerdir?

Bu soruları cevaplamak için aşağıdaki hipotez/denenceleri oluşturduk:

- Cezayirli aileler, çocuklarına din öğretiminde öncelikle İslam'ın inanç esaslarını tercih etmektedirler.

- Cezayirli aileler, çocuklarına din öğretiminde İslam'ın beş şartını öğretmeye gayret etmektedirler.

- Cezayirli aileler, çocuklarına din öğretiminde, Kur'an'dan sure ve duaları öğretmeyi önemsemektedirler.

- Cezayirli aileler, çocuklarına din öğretiminde, Kur'an ezberletmeye okul öncesi dönemde başlamaktadırlar.

- Cezayirli aileler, çocuklarına din öğretiminde, aile içinde teşvik ve sakındırma yöntemini kullanmakta ve Allah sevgisini telkin etmeyi esas almaktadır.

- Cezayirli aileler, çocuklarına din öğretiminde, hikâye ve atasözlerini kullanma yöntemlerini tercih etmektedirler.

- Cezayirli aileler, çocuklarına din öğretiminde, hikâye ve atasözlerini kullanmada kız ve erkek çocuklarına göre farklılıklar vardır.

83

Çocuk ve Medeniyet $2021 / 2$

\section{Araştırmanın Yöntemi}

Yöntem, Madeline Grawitz'e göre bir amaca veya hedefler kümesine ulaşmak için koordineli süreçler dizisidir. Yöntem sistematik araştırmalara yönlendiren ilkelerden oluşmaktadır. Yöntem, çalışmaya yardımcı olacak ve 
belirli bir amaca göre bir çalışma planı aracılığıyla tekniklerin seçimine izin veren bir dizi ölçüt demektir (Grawitz, 1993, s.10-11).

Biz araştırmamızda, Raymond Beaudon'un tanımladığı gibi, konumuzun çerçevesine uygun olması nedeniyle nicel yöntemi ve anket tekniğini kullandık. Çünkü nicel yöntem, araştırmacının bir dizi öğenin karşılaştırmasına dayalı olarak bilgi toplamasına imkân sağlayan araştırma yöntemidir. Yapılacak karşılaştırma ile olgunun sayısal olarak ortaya konulmasına izin vermekte ve bu da araştırmacının yapacağı analizlere yardımcı olmaktadır (Boudon, 1970, s.31).

\section{Örneklem}

Kapsamlı bir anket yürütmenin zorluğu ve çocuk sahibi olan ailelerin tam bir listesinin olduğu veri tabanına sahip olamadığımız için evreni eksiksiz olarak temsil eden bir örneklem bulmanın zor olması nedeniyle biz çalışmamızda araştırma evreninin bir alt kümesini test etmeye izin veren bir işlemler dizisi olan örneklem (Angers, 1997, s.229) kullanımına başvurduk. Angers'in örneklem grubunun bilinmediği ve bu nedenle problemi oluşturan örneklemin evreni ne düzeyde temsil ettiğinin bilinmediği kasıtlı örneklem olarak adlandırdığı (Angers, 1997, s.229) bir yöntemi tercih ettik. Bu, araştırmacı tarafından elindeki bilgiler ışı̆̆ında evrenin bir alt kategorisinin seçilmesi (El Hamali, 1988, s.170), yani katılımcıların durumlarının belirlenmesi şeklinde gerçekleşmiştir.

Bu çalışmada ankete katılanların 3 yaşından büyük en az bir çocuğu olan ve başkent Cezayir'de yaşayan ebeveynler olmasına özen gösterdik.

Tanımlayıcı istatistiksel yöntemi kullandı̆̆ımız bu çalışmada, konuyu oluşturan evreni tanımaya imkân veren örneklemler kullanılmaktadır.

$\mathrm{Bu}$ araştırmada imkânlar çerçevesinde araştırmaya konu olan bütün bir evreni kapsayacak bir örnekleme ulaşılmaya çalışıldı. Araştırmada en az üç yaşında çocuğu olan ebeveynler tarafından cevaplanmasını istediğimiz anket formu kullanılmıştır. Anket formu, 18'i kapalı ve kendi gözlemlerini ifade edebilmeleri için de 7'si açık uçlu olmak üzere toplam 25 soruyu kapsamaktaydı. Ancak bu makalede sadece din eğitimiyle ilgili olanlar ele alınmıştır. Örneklem toplam 385 aileden oluşmakta ve katılımcılar başkent Cezayir'de ikamet etmektedirler. Araştırma Nisan 2015 tarihinde gerçekleştirilmiştir. 


\section{Çalışmada Kullanılan Kavramlar}

Çalışmadan elde edilen sonuçları tartışmadan önce iman, ahlak ve eğitim kavramlarının tanımı ele alınacaktır.

\section{İman}

Genel anlamıyla İslam, yalnız Allah'a yönelme ve şirkten uzak durmak yani bütünüyle Allah'a yönelme ve O'nun emirlerine tam teslimiyettir (Kutub, 2001, s.9). Çünkü Yüce Allah; “Bütün benliğini Allah'a teslim eden, daima iyilik yapan ve her türlü bâtıldan yüz çeviren İbrahim'in inanç sistemine -Allah'ın o'nu sevgisiyle yücelttiğini görerek- uyan kişiden daha iyi iman sahibi kim vardır?"3 buyurmaktadır.

İman, insanın Yüce Allah'la tam bir bağlanma ve ilişki kurmasıdır. Peki, insan imanla nerede ve nasıl yükümlü olacaktır? Yaratıcı olan Allah'ın yarattıklarıyla kurduğu genel ilişkinin aksine, insan kendi yaratıcısıyla, özel bir biçimde kuracağı bağlantı yoluyla iman edecek ve böyle yükümlü olacaktır. Demek ki iman, kişiyi sorumlu bir varlık konumuna da yükseltmektedir. Buna bağlı olarak insan, kendisi için onurlu ve saygın bir konumu güvence altına da almış olacaktır. Böylece kendisine bahşedilen yeryüzünde Allah'ın halifesi olma sıfatı gibi bir yüce değere sahip olacak, kendisini yükümlü kıldığı emanetini üstlenecek ve nihayet cenneti elde edebilecektir. Buna göre küfür/inkar kavramı, imanın bu şekilde anlaşılmasına bağlı olmaktadır. Çünkü "küfür/inkar”, Yüce Allah ile bağlantıyı koparma anlamına gelmektedir.

Öyleyse iman, inanan bireyin saf ve temiz nitelikleriyle tüm davranışlarının üzerine kurulduğu, sahip olduğu kişiyi nimetlerle dolu cennetlere ulaştıracak olan sağlam bir temeldir (İbni Teymiyye, 1993, s.3).

\section{Ahlak}

İslam ahlak üzere kurulu bir toplum oluşturmak için gelmiştir. Bu nedenle ahlak İslam'ın temeli ve esası olarak görülmektedir. Ahlak, insanın tutum ve davranışlarının dosdoğru bir biçimde olmasını sağlayan kontrol ilkeleri demektir. Ahlak sayesinde insan, Allah'a kulluğun en ulvi derecesine yükselmek için, nefsini bencilliğin kirlerinden arındırır. Bu hak dinin ve onun hoşgörülü mesajının asıl amacının ahlak olduğunu gösteren pek çok

3 Nisa, 4/125. 
tamamlamak üzere gönderildim."4 hadisidir. İslam'da ahlak sistematiği bir takım ilkeler üzerine kuruludur. Bunlar:

a. Fitrat İlkesi: Buna göre insan bir dine bağlanma, iyilik, doğruluk, tanışma ve toplumla uyum içerisinde olma gibi fitri özelliklere sahiptir.

b. Bir dine bağlanma ilkesi: Ahlakın insanın üzerinde yaratıldığı bir fitrat olduğu düşünüldüğünde, dinin rolü de bu fıtratı belirgin hâle getirmek, mükemmelleştirmek ve arındırmak olmaktadır.

c. Kapsamlılık İlkesi: Ahlak sistemi, insanın yaratıcısıyla ilişkisini ve insanın hemcinsleriyle ilişkisini içermesi açısından kapsamlı ve genel bir özelliğe sahiptir.

Ahlak erdemi, İslam'ın bireyi inşa etmede ve toplumu islah etmede benimsediği en önemli temellerden birisi olarak kabul edilir. Çünkü onunla hem dinî eksiklikleri giderilmiş hem de dünya ve ahireti kurtulup düzene girmiş olacaktır.

Ahlak, iyi ya da kötü olsun insanın iradesiyle seçmiş olduğu davranışların kendisinden kaynaklandığı nefiste yerleşik olan bir durumdur. Dolayısıyla birey, doğal olarak iyi ya da kötü bir biçimde yetiştirilmenin etkisine girebilmektedir. Eğer bir birey, erdemi ve hakikati tercih etme, iyilik sevgisi, faydalı şeyleri yapma ve kötülükten uzak durma arzusuyla yetiştirilirse bu onun karakteri hâline gelecek, hiç zorlanmadan kolay bir biçimde güzel davranışları sergileyebilecektir. Tam tersi bir biçimde bu ihmal edildiğinde ya da kötü bir şekilde yetiştirildiğinde, ihanet, yalan, açgözlülük, yabancılaşma vb. olumsuz ahlaki davranışları hiç zorlanmadan ortaya koyabilecektir (Abdülmü'min, 2004, s.16).

\section{Terbiye/Eğitim}

İbni Sina terbiyenin, bireyleri din ve dünya için aynı anda hazırlamanın bir vesilesi olduğunu söyler. Birey eğitimle zihinsel ve ahlaki olarak, yeteneklerine ve kişisel yapısına uygun bir sanat edinebilir ve geçimini sağlayabilir (ez-Zintati, 1993, s.24).

İslâmî eğitimin amaçladığı hedef çocuğun, Cenâb-1 Hakk'a tam anlamıyla kulluk yapabiliyor denilebilecek bir dereceye ulaşmasıdır. Bunu İbni Teymiyye şöyle dile getirmektedir: “O, Allah'ın sevdiği ve razı olduğu söz ve davranışta, içten ve dıştan yapılan her şeydir. Namaz, zekât, oruç, hac, sözde doğruluk, emaneti yerine getirme, ana-babaya saygı, akrabalık bağlarını koruma, verilen sözleri yerine getirme, iyiliği emretme ve kötülükten 
sakındırma, kâfir ve münafıklarla mücadele etme, komşuya, yetime, muhtaca, yolcuya iyilik etme, dua, zikir, Kur'an okuma ve benzeri şeyler hep ibadettir." (İbni Teymiyye, t.y., s.149).

Müslüman toplumlarda, insanın yetiştirme ve ahlakını güzelleștirme hedefleri doğrultusunda, eğitim müfredatı ve yöntemi geleneği oluşmuştur.

\section{Yönlendirme ve Rehberlik Etme Yöntemi}

Hz. Peygamber'in (sav) hayatı, yönlendirme ve nasihat alanında yol gösteren birçok tutum ve direktif içermektedir. Örneğin İbni Abbas’a yönelik olarak yönlendirme ve yol gösterme anlamında şöyle buyurmuştur: "Evlâdım! Sana bazı sözler öğreteceğim: Allah'ı(n hakkını) koru ki O da seni korusun. Allah'1(n hakkını) koru ki O'nu hep yanında bulasın. Bir şey isteyeceğin zaman Allah'tan iste. Yardım dileyeceğin zaman Allah'tan yardım dile. Şunu bilmelisin ki bütün toplum bir konuda senin yararına bir şey yapmak için bir araya gelse, ancak Allah yazmışsa sana destek verebilirler. Yine onlar bir konuda sana zarar vermek için bir araya gelse, ancak Allah yazmışsa sana zarar verebilirler. Artık kalem kalktı, yazgı bitti."5

Bu yöntem, insan nefsini tedavi etmenin ve düzeltip ıslah etmenin en önemli aracı olup, müminlerin kalplerini yumuşatan ve katılaşan ruhları incelten bir yöntemdir. Yumuşak ve ısrarlı bir şekilde sürdürülmesi hâlinde bu yöntem, bireyin davranışlarında büyük bir değişiklik meydana getirir. Günahların ve kötülüklerin izlerinin ortadan kaldırılmasına neden olabilecek bir teşvik ve korkutma yolu tercih edilmelidir. İstenmeyen davranışların yerine erdemler ve salih davranışlar kişiye alternatif olarak sunulmak suretiyle Hz. Peygamber (sav)'in yöntemi izlenmelidir.

Rehberlik etme ve yol gösterme, ulvi hedefleri olan bir Kur'an eğitim yöntemidir. Bu yöntemin en önemli amacı, yeryüzünde Müslüman bireye verilen en büyük sorumluluklardan ve en önemli görevlerden biri olan bireyin ve toplumun ıslahı/düzeltilmesidir. Aynı şekilde bir mümin için en büyük arzu olan Allah'ın rızasını kazanma da bu hedeflerdendir. Çünkü dosdoğru yoldan ayrılıp sapan Allah'ın kullarına şefkat göstermek ve onları kendi kötülüklerinden İslam'ın güzelliklerine yönlendirmek önemlidir.

Lider konumunda olan bir rehberin, yol göstericinin, köklü ve sağlam bir imana sahip olması, ilim, iffet, vakar, sabır, fedakârlık ve şefkat sahibi

5 Tirmizî, Sıfatü'l-Kıyâme, 59. 
erdemleri göstermelidir. Zira söylediklerine kalpten samimi bir şekilde inanmayan bir kimse, hiçbir şeyi anlatıp iletemez ve sözlerinin de bir etkisi olamaz.

\section{Örnek/Rol Model Olma}

Örneklik oluşturma, bireyin yetiştirilmesini ve davranışlarının düzeltilmesini etkileyen en önemli yöntemlerden biri olarak kabul edilir. Örneğin bir çocuğun güzel bir davranış örnekliğiyle eğitilmesi, sözlü bildirimlerden daha etkili olacak ve bizzat uygulayıp gösterilerek yapılan bir yol gösterme yöntemi, insan ruhunda daha fazla etkisini gösterecektir.

Çoğunlukla anne babadan oluşan yol gösterici kişilerin, imanlarının sağlam, derinlikli, saf ve temiz, ilimle, iffetle donanımlı, haysiyet, sabır, fedakârlık ve merhamet gibi niteliklere sahip olmalıdırlar. Çocuklarına rol model olabilmeleri için sözleriyle eylemlerinin örtüşmesi gerekmektedir.

Güzel örneklik ilkesini, Kur'an-1 Kerim'den ve kendisinde söz ve davranışlarıyla Müslümanlara rol model olan Hz. Peygamber'in (sav) şahsiyetinden çıkarıyoruz. O, İslamıın emir ve yasaklarıyla tecessüm ettiği yegâne örnek olarak takip edilmesi gereken en yüce modeldir. Çünkü Hz. Peygamber'in kutlu yaşantısı, amaç ve niyette samimi olunduğu takdirde, Müslüman bireyin eğitiminde, davranışlarını değiştirmesinde ve ruhunu arındırmasında çok önemli bir yere sahiptir. Hz. Peygamber (sav), ahlak bakımından insanların en iyisi ve güzeliydi. Çocuklarla oynar ve onlara iyilikle davranırdı, ayrıca cömertliği, Allah yolunda harcaması ve hayır işlerine düşkünlüğü ile tanınırdı. Fakir muhtaçlara yardım konusunda yiyecek bir şey bulamasa bile başkalarını kendi nefsine tercih ederdi. İnsanların en cesuruydu ve kendisine kötülük edenleri bağışlardı ve çok sabırlıydı. Dostlarına sevgi ve şaka ile muamele eder, kendisini davet edenlerin davetine icabet eder, hastaları ziyaret eder, kimseyi kınamaz ve ayıplamazdı. Dünya hayatına değer vermezdi, en çok ahiret için gayret eden birisiydi (El Useymin, 2001, s.53-62).

\section{Kissa Yöntemi}

Bir eğitim yöntemi olarak kıssa, insan ruhuna imanı yerleştiren ve derinleştiren, kalplere doğru inanç ilkelerini benimsetmede müminlere yol gösteren bir özelliğe sahiptir. Kıssa yöntemi, ögüt vererek bireyleri

Çocuk ve Medeniyet 2021/2 uyarmakta, gafletlerinden uyandırmakta, zihinlerde Allah'ın belirlediği kuralların idrak edilmesini ve onlardan gerekli dersler çıkarmalarını sağlamaktadır. 
"İ̧ste size Allah'tan bir nur ve apaçık bir kitap (Kur'an) gelmiştir." 6 buyurulan Allah'ın kitabı dini kuşatıcı ve kapsayıcı bir niteliktedir.

Örneğin peygamber kıssalarında, onların hikmet, akıllarının gücü ve görüşlerinde isabet gibi özellikleriyle diğer insanlardan farklı ve onların en hayırlıları olduğu ifade edilir. Onların hayatını inceleyen bir kimse, farklı dönemlerde düşüncelerinde, ruhlarında ve davranışlarında ortaya çıkan sapmalarla yüzleşmenin yol, yöntem ve yaklaşımlarını öğrenmiş, kıssalarda anlatılan deneyim örneklerini somut olarak görmüş olacaktır.

Kur'an'da sözü edilen kıssaların hedefleri arasında, insanın gerçekliğini ele almak, tutum ve hatalarını düzeltmek, hayata ilişkin problemleri gündeme getirerek onları ahlaki ve sosyal açıdan mükemmelliğe ulaştırmak vardır.

Kur'an kıssaları, olayları ve anlamlarını düşünmek, sorgulamak, onlardan ibret almak ve hayatımıza yansıtmak için aktarılmıştır. Kıssalarda, insan davranışlarının hangi alanlarında sapmaların olduğu, bunların Kur'an'ın rehberliğinde nasıl düzeltileceği örneklerle ele alınmıştır. Önceki milletlerin hayat hikâyeleri örnek alınarak, yaratılıştaki ilahî yasalar ışığında insanlığın onurlu ve şerefli bir geleceğe sahip olması gerektiği vurgulanmıştır.

\section{Bulgular ve Yorumlari}

Cezayirli çocukların din ve ahlak eğitimiyle ilgili verilere ulaşabilmek için ilk önce, yukarıda iman, ahlak ve eğitimin tanımları verilmişti. Bu bölümde, Cezayir'de ailelerin, çocuk eğitimi konusunda nasıl davrandıkları ve teori ile uygulama arasında nasıl bir fark olduğu, anket bulgularına göre açılanmaya çalışılacaktır.

\section{Cezayirli Ailelerin Çocuklara Din Öğretiminde Tercihleri}

İslam, çocukların doğru bir şekilde yetiştirilmesi ve onların hem dinlerine ve hem de toplumlarına faydalı olmaları için en uygun şekilde yetiştirilmelerine önem vermiştir. Ailenin İslami eğitim konusundaki rolü ve etkisi herkes tarafından kabul edilmektedir. Ailenin bu konuda olumlu rolünün yanında, yapılacak hataların da bir o kadar tehlikeli sonuçları olacağı açıktır. Çünkü aile, çocuğa doğumdan büyüyüp gelişene kadar eşlik eder ve o nihayet kendine güvenen bir yetişkin hâline gelir. İslam, çocuğu erken yaşlardan itibaren tevhit inancı üzerine yetiştirilmesine özen göstermiştir. Bu nedenle tüm Müslüman toplumlarda olduğu gibi, Cezayir toplumunda da doğum sonrasında kulağına ezan okunması geleneği vardır. 
İslam'ın öngördüğü tevhit inancı, kişinin Allah'tan başka yaratıcı ve her şeye malik birinin olmayacağını ikrar etmesiyle sınırlı değildir. Tam tersi tevhit, Allah sevgisini, ona boyun eğmeyi, ibadetlerde içtenliği, bütün söz ve davranışlarda sadece onun hoşnutluğunu gözetmeyi içermektedir (esSallabi, 2011, s.11).

İşte bu çalışmada Cezayirli ailelerde çocukların İslami terbiye ile nasıl yetiştirdiklerini araştırmak istedik, elde edilen verilerin istatistiksel bir analizini şöyle yaptık:

Tablo:1 Ailelerin Çocuğun Yaşına Göre Din Öğretiminde Tercihleri

\begin{tabular}{|c|c|c|c|c|c|c|c|c|c|c|}
\hline \multicolumn{11}{|l|}{ Tercihler } \\
\hline \multirow[t]{2}{*}{$\begin{array}{l}\text { Çocuğun } \\
\text { Yaşı }\end{array}$} & \multicolumn{2}{|c|}{$\begin{array}{l}\text { Kur'an'ın } \\
\text { ezberletilmesi } \\
\text { isteği }\end{array}$} & \multicolumn{2}{|c|}{$\begin{array}{l}\text { Güzel/ahlaki } \\
\text { davranışların } \\
\text { öğretilmesi ve } \\
\text { uygulatılması }\end{array}$} & \multicolumn{2}{|c|}{$\begin{array}{l}\text { Öğüt ve } \\
\text { yönlendirme }\end{array}$} & \multicolumn{2}{|c|}{$\begin{array}{l}\text { İslam'ın } \\
\text { beş şartının } \\
\text { öğretilmesi }\end{array}$} & \multicolumn{2}{|c|}{ Toplam } \\
\hline & $\mathrm{S}$ & $\%$ & $S$ & $\%$ & $S$ & $\%$ & $S$ & $\%$ & $\mathrm{~S}$ & $\%$ \\
\hline $3-6$ & 12 & 24 & 30 & 60 & 1 & 2 & 7 & 14 & 50 & 100 \\
\hline $6-9$ & 40 & 43,96 & 31 & 34,06 & 10 & 10,98 & 10 & 10,98 & 91 & 100 \\
\hline $9-13$ & 34 & 23,77 & 15 & 10,98 & 35 & 24,47 & 59 & 41,29 & 143 & 100 \\
\hline $13-15$ & 14 & 13,86 & 10 & 9,9 & 48 & 57,52 & 29 & 28,71 & 101 & 100 \\
\hline Toplam & 100 & 25,97 & 86 & 22,34 & 94 & 24,41 & 105 & 27,27 & 385 & 100 \\
\hline
\end{tabular}

Tablo: 1'de gördügüumüz gibi sorumuza cevap veren Cezayirli ailelerin, İslam'ı bir bütün olarak öğretme çabaları vardır. "Çocuklarınıza dini öğretirken hangi yaşta hangisini tercih ediyorsunuz?" sorusuna verilen cevaplarda, İslam'ın beş şartının öğretilmesi \% 27,27 oranında olup onu \% 25,97 gibi yüksek oranda Kur'an-1 Kerim'i ezberletme arzusu ile çocuklara dinî sorumlulukları hatırlatıp öğretme tercihi takip etmektedir. Buna karşın \% 22,34 oranında aksırana dua etmeyi, esnerken eli ağza götürmeyi, sağ el ile yemeyi, tuvalet adabını, selam verip alma adabını, misafiri ağırlamayı, başkalarıyla yardımlaşmayı vb. tutum ve davranışlar gibi güzel ahlakı öğretme gelmektedir. Bu tablodan ailelerin en çok 9-13 yaş grubundaki çocuklara eğitim verdiği sonucunu ve 3-6 yaş grubunun en az eğitim verilen yaş grubu olduğunu söyleyebiliriz. Aynı şekilde çocuklara en çok Kur'an-1 Kerîm öğretildiği yaş aralığının 6-9 olduğunu da söyleyebiliriz.

Çocuk ve Medeniyet 2021/2
Anne babaların çocuklarına ahlak ve görgü kurallarını öğretmedeki tercihlerini bağımsız değişken olan çocuğun yaşına göre 
değerlendirdiğimizde; 3-6 yaş grubundaki çocuklara en yüksek oranda (\%60) güzel ahlaki tutum ve davranışların telkin edildiği ortaya çıkmaktadır. Velilere göre çocuklar, bu adab ve ahlaka, güzel davranışlara küçük yaşlardan itibaren alıştırılmaları hâlinde, çocuk bunları benimseyecek ve ileriki yaşlarında bunlar birer davranış ve alışkanlık hâline gelecektir. Bu tutum veya tercih psikolojik açından çok önemli ve iyi bir tercihtir. Çünkü okul öncesi yani erken çocukluk döneminde öğretilmesi gereken, ahlak ve değerlerdir. Bilinmektedir ki, insan kişiliği büyük ölçüde küçük yaşta oluşmaktadır. Kişilik, bireyin doğuştan getirdiği mizaç ve sonradan kazandığı karakterin bileşkesidir. Özellikle eğitim yoluyla kazandığımız karakter özellikleri ve görgü kuralları erken yaşta kazanılmaktadır.

Dinin inanç, ibadet, ahlak ve muamelat bölümleri/alanları vardır. Öğretim açısından bu alanların/bölümlerin öğretim yöntemleri ve öğretme yaşları çok farklıdır. Çocuk somut alandaki öğrenmelerle başlar ve gittikçe soyut konuları öğrenmeye devam eder. Buna göre, çocuğa önce somut görgü kuralları ve ahlaki davranışlar ile ibadet ilkeleri öğretilmeli, daha sonra soyut olan inanç esasları öğretilmelidir. Bu açıdan bakıldığında Cezayirli anne babaların, tercihlerinin çocuk gelişimi ve öğrenme psikolojilerine uygun olduğunu söyleyebiliriz.

İslam'a göre bir Müslüman günde beş vakit namaz kılmalıdır. ${ }^{7}$ Namazın şartlarından biri de Kur'an'dan bir sure veya ayetler okumaktır. Bu da din eğitiminde çocuklara Kur'an öğretilmesi gereğini ortaya çıkarmaktır. Cezayirli ailelerin din öğretiminde, 6-9 yaş aralığındaki çocuklara \% 43,96 oranında Kur'an ezberletilmesi öne çıkmaktadır. Ebeveynlere göre çocuk bu yaşlarda Kur'an'ı öğrendiği takdirde, ana babaların camilerde ve diğer yerlerde düzenlenen zikir meclislerine ve dinî programlara eşlik etmesi, çocukların geçmiş İslam büyüklerini örnek alarak takip etmelerini sağlayabilecektir. Cezayirli anne babaların 6-9 yaşlarda çocuklarına Kur'an ezberletmeleri çocuk psikolojisine uygundur. Çocuklar bu yaşta ezber yapmaya yeterli ve yatkındır. Ancak verilere topluca yani 385 ailenin tamamına baktığımızda, Kur'ân-1 Kerîm ezberletilmesi isteği olan ailelerin oranı sadece \% 25,97'de kalmıştır. Bunu tersten okuduğumuzda Cezayirli ailelerin yaklaşık \%75 oranında Kur'an-1 Kerîm ezberlettirilmesine önem vermedikleri sonucu da aynı tablodan çıkartılabilir.

9-13 yaş grubunda olan çocuklara yönelik olarak ailelerden $\%$ 41,96 oranındaki çoğunluğun İslam'ın beş şartını emrettiği görülmektedir. Örneğin

Çocuk ve Medeniyet 2021/2
7 “Gündüzün güneşin gün ortasını aşmasından gecenin karanlığına kadar namazı kıl; bir de sabah namazını; çünkü sabah namazı şahitlidir.” İsra, 17/78. 
çocuk yedi yaşına geldiğinde Hz. Peygamber'in (sav) sözü gereği namaz emredilmektedir. Nitekim Hz. Peygamberden rivayet edildiğine göre şöyle buyurmuştur: "Yedi yaşına geldiklerinde çocuklarınıza namazı emredin. On yaşlarında namazı kılmıyorlarsa (hafifçe) dövün ve yataklarını ayrın."8

Benzer şekilde aileler, çocukları buluğa ermeden önce oruç tutmaya alıştırmaktadırlar. Büyüdüklerinde güç yetirebilmeleri için çocuklara, günde bir-iki saat ya da günün yarısı gibi zaman dilimlerinde oruç tutturulmaktadır. Böylece Allah'a boyun eğme, emirlerini yerine getirme ve O'na şükür edebilme anlayışına göre yetiştirilmektedirler. Hz. Peygamber'in (sav) bize gösterdiği örnekte olduğu gibi; Rubeyyi binti Muavviz'den aktarıldığına göre o şöyle demiştir: Aşure günü sabahı Hz. Peygamber (sav) Ensar köylerine birisini göndererek şöyle dedi: "Kim sabahleyin bir şey yemeksizin duruyorsa, orucunu tamamlasın, kim sabahleyin bir şeyler yemiş ise günün kalan kısmında bir şey yemeden (oruçlu gibi) devam etsin." Biz de bundan sonra oruç tutuyor, küçük çocuklarımıza da -inşallahtutturuyorduk. Mescide gidiyor onlara yünden oyuncaklar yapıyorduk. Onlardan birisi yemek için ağladığında ancak iftarda o yiyeceği veriyorduk." ${ }^{9}$

Namaz ve oruç öğretiminde Cezayirli anne babaların, çocukların yaşlarına uygun olarak hareket ettikleri görülmektedir. Aynı şekilde, inanç esaslarının öğretiminde de eğitim/gelişim psikolojisinin verilerine uymaktadırlar.

Buna eğitim literatüründe çocuğa/öğrenene/muhataba görelik ilkesi denilmektedir. Bunu ilk olarak Peygamberimiz söylemiştir. O bir hadiste şöyle buyurur: "İnsanlara akılları ölçüsünde konuşun." ${ }^{10} \mathrm{Bu}$ eğitim ilkesini, daha sonra Batıda J.J. Rousseau dile getirdi. Rousseau'nun görüşlerinden sonra eğitim psikolojisi, öğrenme psikolojisi ve gelişim psikoloji olarak iki alanda gelişti.

Son olarak yaşları 13-15 arası olan çocuklarda \% 57,52 oranında genellikle aileler tarafından çocukların Allah'ın azabından korkutma ve sakındırma gibi öğüt ve yönlendirmeleri kullandığını görmekteyiz.

Bu sonuçlar, ailelerin çoğunun, çocuklarını erdemli davranışlara alıştırması nedeniyle İslami eğitimle yetiştirmeye çalıştıklarını göstermektedir. $\mathrm{Bu}$ açıdan bakıldığında ailelerin çocuklarına, İslam dini ile çelişmeyen medeniyet verilerinden mümkün olduğunca istifade etmek suretiyle, İslam dinini öğretmek için çaba sarf ettiklerini ortaya koymaktadır. Çünkü doğru rehberlik ve yol gösterme, çocuğun dinî kavramları açık ve düzenli bir 
şekilde öğrenmesine yardımcı olacaktır. Bu nedenle de her aile, istenen hedefe ulaşmak için en iyi ve en etkili yolları izlemeye çalışır.

Cezayirli aileler için İslami eğitimin nihai amacını, çağdaş yöntemlerle, çocuğu duygu, düşünce, inanç ve davranış uyumuna sahip bir kişi olarak, milletinin mensubu yapmak şeklinde özetleyebiliriz. Böylece Cezayirli bir birey, çocukluğundan başlayarak gençliği ve yaşlılığı boyunca gerçek anlamda nebevî mesajın taşıyıcısı olacaktır.

\section{Cezayirli Ailelerin Çocuklara İnanç Esaslarını Öğretmede Tercihleri}

Her din gibi İslam dini için de inanç esasları dinin özünü ve temelini oluşturur. İslam'ın inanç esasları imanın şartları şeklinde formüle edilmiştir. ${ }^{11}$ İslam, iman esaslarıyla, kişiliği, zihinsel ve ruhsal bütünlük içinde oluşturmaya ve geliştirmeye önem verir. Kur'an-1 Kerim de bu yöntemi kullanır ve Allah'ın gözetimi ve değerlerin içselleştirilmesi gibi imanın olumlu sonuçlarının güçlendirilmesini sürekli vurgulamaya çalışır. Nitekim Yüce Allah, bir ayette şöyle buyurmaktadır: "Şüphesiz, Rabbimiz Allah’tır deyip, sonra dosdoğru yolda yürüyenlerin üzerine melekler iner. Onlara: Korkmayın, üzülmeyin, size vâdolunan cennetle sevinin, derler."12

Buradan hareketle, İslam doktrininin temeli tevhit inancıdır, mümin kesin bir inançla yaratıcısına bağlı olmalı; bir tek yaratıcıya ibadet etmeli ve O'na hiçbir şeyi asla ortak koşmamalıdır, denilebilir. Böylece O'nun dışındaki hiçbir şeye değil sadece O’na kulluk edebilmesi sağlanır. Çünkü sadece düşüncedeki bir İslam, ahlaki davranış oluşturmak için yeterli değildir.

İslam inancı dört ana bölüme ayrılmakta ve her bölümün altında da alt bölümler bulunmaktadır. Bunların ilki insanın yaratıcısına inanmasını içeren ilahiyattır. İkincisi, insanların rehberliğe olan ihtiyacını gideren peygamberlere ve kutsal kitaplara imandır. Üçüncüsü ruhiyat olup, maddi olmayan âlemle ilgili olan yani melekler, cinler ve ruhlar gibi konulara ilişkindir. Sonuncusu ise semiyyatla yani işitmekle öğrenilebilen nakle bağlı konular olup ahiret hayatını ilgilendiren kabir halleri, kıyamet alametleri, hesap, cennet, cehennem gibi şeyleri içermektedir (El Beyanuni, 1985,

11 Bir hadiste bu şöyle ifade edilmiştir: (Melek) Cebrail: "Ey Muhammed! İman nedir? Açıklar mısın?" deyince; Peygamberimiz (sav) buyurdu ki: "Allah'a, meleklerine, 
s.22). Bu birinci bölümün içine Allah'ın her şeyi bilmesi yani kadere imanı da dahildir. Çocuğun yaşı ve cinsiyeti bağlamında, aile tarafindan kendisine öğretilen korkutma ve sakındırma konularının tercihine ilişkin olarak aşağıdaki tablo verilerine bakalım:

Tablo 2. Ailelerin Çocuklara İnanç Esaslarını Öğretmede Tercihleri

\begin{tabular}{|c|c|c|c|c|c|c|c|c|c|c|}
\hline \multicolumn{11}{|l|}{ Tercihler } \\
\hline \multirow[t]{2}{*}{$\begin{array}{l}\text { Çocuğun } \\
\text { Yaşı }\end{array}$} & \multicolumn{2}{|c|}{$\begin{array}{l}\text { Allah'a Şirk } \\
\text { Koşmaması }\end{array}$} & \multicolumn{2}{|c|}{$\begin{array}{l}\text { İlk başta } \\
\text { Peygamberi } \\
\text { sevmesi }\end{array}$} & \multicolumn{2}{|c|}{$\begin{array}{l}\text { Ahiret } \\
\text { gününe } \\
\text { inanması }\end{array}$} & \multicolumn{2}{|c|}{$\begin{array}{l}\text { Meleklere } \\
\text { iman }\end{array}$} & \multicolumn{2}{|c|}{ Toplam } \\
\hline & s & $\%$ & S & $\%$ & $s$ & $\%$ & s & $\%$ & S & $\%$ \\
\hline $3-6$ & 25 & 40 & 7 & 14 & 3 & 6 & 20 & 40 & 50 & 100 \\
\hline $6-9$ & 80 & 87,91 & 5 & 5,49 & 1 & 1,09 & 5 & 5,49 & 91 & 100 \\
\hline $9-13$ & 100 & 69,93 & 20 & 13,98 & 20 & 13,98 & 3 & 2,06 & 143 & 100 \\
\hline $13-15$ & 99 & 98,02 & 1 & 0,99 & 1 & 0,99 & 1 & 0,99 & 101 & 100 \\
\hline Toplam & 304 & 77,40 & 33 & 8,57 & 25 & 6,49 & 29 & 7,53 & 385 & 100 \\
\hline
\end{tabular}

Ailelere, "İslami terbiyede çocuklara inanç esaslarını öğretirken tercih ettiğiniz konu nedir?” şeklinde bir soru yöneltilmiştir. Ailelerin çocuğun eğitiminde korkutup sakındırdığı ilk tutum, \% 77,40 oranında Allah'a hiçbir şeyi ortak koşmamasıdır. Bu oran, Tablo 2'de görüldüğü gibi, çocuğun farklı yaş gruplarıyla tutarlıdır. Ailenin çocuklarına karşı en önemli görevlerinden biri de Allah'a olan tevhit inancı ile fitratı sapmalardan korumaktır.

Buna karşılık ailelerin \% 8,57'si öncelikle çocuklarına, cennete girmenin ilk şartı olarak Hz. Peygamber sevgisini öğretmektedirler. Bazı Cezayirli aileler, Hz. Peygamber sevgisinin Allah'a olan sevgiden kaynaklandığına inanarak, Hz. Peygamber'in sevgisini çocuklarının kalbine yerleştirmek için çaba sarf ederler. Çünkü onlara göre şu hadiste de ifade edildiği gibi bir kişi ancak Allah'1 ve Peygamberi sevmekle mümin olabilir: "Sizden birinize ben babasından, çocuğundan ve diğer tüm insanlardan daha sevimli olmadıkça (tam anlamıyla) iman etmiş olamaz."13

Ailelerden \% 7,53 oranındaki bir kesim, cennete girebilmek için çocuklarına, meleklere inanmaları gerektiğini öğrettikleri görülmektedir. Bilindiği gibi melekler, Allah'ın emrinde olup emredildikleri şeyleri yerine getirip hiçbir şekilde O'na karşı çıkmazlar. Yeryüzünde niteliklerini sadece

13 Buhari, İman, 8. 
Allah'ın bildiği, bizim bilmediğimiz birçok varlık bulunmaktadır. Melekler de bunlardandır. Kimi ailelerin çocuklarına bu gaybî iman ilkesinden bahsettiklerini eldeki veriler ortaya koymaktadır.

Bu nedenle, Cezayirli aileler arasındaki İslam anlayışının, bakış açılarını o bir tek Yaratıcı'ya olan inançlarında birleştirebildikleri sonucuna ulaşıyoruz. Yani bireyin kişilik gelişimi yönünde emrine amade kılınanlar sayesinde bütünüyle ona teslim olması, hayata ilişkin izlenecek şeyleri O'ndan alarak sadece O'na ibadet etmesi ve varlık âleminde olanlar için belirlediği ilahi kurallar olan kozmik kanunlarına boyun eğilmesi için böyle olmalıdır.

Cezayir ailesi, tevhit inancı çerçevesinde Allah'ın eşsiz ulûhiyetine ilişkin apaçık gerçekleri ve insanların bütünüyle benimseyip katıldığı kulluğun özünü fark etmiştir. Böylece, hiçbir ortağı olmayan Allah'a gerçek kullukta temsil edilen İslami eğitimin genel amacına ulaşma yolunu tutmuştur. Bu da çocukların doğru bir inanç üzere yetiştirilmelerini gerektirmektedir. Amaç, hiç kuşkusuz akıbetleri cennet olacak olan, bir basiret ve hidayet yoluyla Allah'a kulluk eden salih bir insan ortaya çıkarmaktır.

Kimi aileler, çocuklarına cennet nimetlerini ve melekleri anlatmakta, yüce Allah'ın şu sözlerinde olduğu gibi İslam dininin korkutup caydırma yöntemini kullanmaktadırlar: "Rabbimiz Allah'tır." deyip sonra da doğrulukta devam edenler, onları, melekler, ölümleri anında: "Korkmayınız, üzülmeyiniz, size söz verilen cennetle sevinin, biz dünya hayatında da, ahirette de size dostuz. Burada, canlarınızın çektiği, umduğunuz şeyler, bağışlayan ve acıyan Allah katından bir ziyafet olarak size sunulur" diyerek inerler. Allah'a çağıran, salih amel işleyen ve 'Kuşkusuz ben Müslümanlardanım.' diyenden daha güzel sözlü kimdir?”14

Öte yandan aileler; Hz. Peygamber'in "Ben güzel ahlakı tamamlamak üzere gönderildim." ${ }^{15}$ buyruğuna uyarak çocuklarını doğruluk, güvenilirlik, samimiyet vb. güzel ahlak ilkelerini benimsetme üzerine yetiştirirler. Böylece çocuklarını Cenab-ı Hakk'a davet, iyiliği emredip kötülükten sakındırma görevini yerine getirmeye hazırlamış olurlar.

Çocuğun yaşına göre değerlendirildiğinde, yaşları ne kadar değişse de tablodaki genel eğiliminin Allah'a şirk koşmaktan uzak tutma hususunda en yüksek düzeyde olduğu görülmektedir. Yaşları 13-15 arasındakilerde bu oran \% 98,02'dir. Yaşları 6-9 arasındaki çocuklarda \% 87,91, yaşları 9-13 arasında olanlarda \% 69,93 ve yaşları 3-6 arasında olanlarda ise \% 40 olduğu ortaya çıkmıştır.

Çocuk ve Medeniyet 2021/2
14 Fussilet, 41/30-33.

15 Muvatta, Husnü'l Halk, 8; Müsned, 2/381. 
Sözün kısası, ailelerin çoğunluğunun sözlerinde, sevinç ve sevgi tutumları çerçevesinde çocuğa Allah'ı hatırlatmayı dikkate aldıklarını görmüş olduk. "Allah onu güzel davranışları dolayısıyla seveceği ve cennetine sokacağı" örneğinde olduğu gibi genellikle sevginin ve umudun anlamı üzerinde yoğunlaşılmaktadır. Aynı şekilde çocuk Kur’an-ı ezberlediğinde Allah sevgisini tatmış olacak ve okulda da iyi bir dereceyi elde etmiş olacaktır.

Özendirme ve sakındırma tercihinin çocuğun cinsiyetiyle ilişkisi ele alındığında, cinsiyetler açısından bir farklılık görülememiştir. Araştırmaya göre çocuklara Allah'a şirk koşmaktan uzak durmaları öğütlenmiştir. Bunlardan erkekler 168 kişi olup \% 80 oranında ve kız çocukları ise 130 kişi olup \% 72,28 oranındadırlar.

\section{Kıssa ve Atasözlerini Kullanma Yöntemi}

Çocuk çevresindeki varlıkları beş duyu ile algılar. Çünkü o, erken yaşlarda olan biteni anlama ihtiyacındadır. İşte kıssalar, şahısları ve olayları içeren şeylere ilişkin olarak çocukta somut bir biçimde anlamların ve fikirlerin ortaya çıkmasına yardımcı olur. Örneğin, her türlü eğitime ilişkin harika örneklerin bulunduğu peygamberlerin hikâyeleri veya Kur'an'daki nebevî kıssalar dile getirilip anlatılır. Bu durumda o çocuk; zevk duyacağı, psikolojik rahatlığın yanı sıra eğitimin yer aldığı peygamberlerin hayatlarındaki olayları da yaşayacaktır.

Peygamberler ashaplarına örnek olarak gönderildiği gibi Hz. Muhammed (sav) de bizlere örnek olmuştur. Abdullah b. Mesud (r), güzel davranışlarında ve yüce ahlaki özelliklerinde Hz. Peygamberin (sav) ashabını takip etmenin gerekliliğini şöyle dile getirir: “ Kim bir örnek ararsa Hz. Peygamberin (sav) ashabını örnek alsın. Çünkü onlar bu ümmetin kalpleri en muttaki, ilimleri en derin, en az gösteriş yapanlarıdır. Yolları en doğru olan ve halleri en düzgün olanlar onlardır. Allah onları Peygamberine yoldaş olmaları ve dinini yerleştirmeleri için seçmiştir. Öyleyse onların üstünlüklerini bilin, gittikleri yolu izleyin. Zira onlar dosdoğru yol üzeredirler." (Ulvan, t.y., s.9).

Ancak bu çalışmada görüşülen ailelerin çoğu $(\%$ 64,03), çocuklarını yetiştirirken kıssa ve atasözleri anlatma yöntemini kullanmadıklarını ifade etmişlerdir. Kıssa ve atasözleri dinî ve ahlaki ilkelerini somutlaştırmaktadır. Somut örnekler, insan ruhunu etkiler ve böylece aktarılan bilgileri ve yönlendirmeleri kabullenmeye hazır hâle getirir.

Çocuklara, "küçüklere, hayvanlara merhamet vb. Hz. Peygamber'in hayatından alıntılanan iyi nitelikleri; Peygamberin arkadaşlarının 
hayatlarından verilen örnekler"le onlar, $\mathrm{Hz}$. Peygamberin ahlakını öğrenecek, böylece, küçüklere ve zayıflara merhamet gösterecek ve örneğin insanlara ve hayvanlara eziyet etmeyecektir.

Aileler çocuklarına Hz. Peygamberin (sav) siyretinden ve arkadaşlarının yaşayışlarından bazı şeyleri anlatmaktadırlar. Böylece "Andolsun ki, Resûlullah, sizin için, Allah'a ve ahiret gününe kavuşmayı umanlar ve Allah'ı çok zikredenler için güzel bir örnektir." 16 ayeti uyarınca onların güzel ahlaklarını örnek edinebileceklerdir.

Çocuğun yaşı değişkenine göre bir değerlendirme yapılacak olursa; ailelerin çocuk eğitiminde kıssa ve atasözlerinin kullanma tercihinde yaşlar biraz daha erken düzeydedir. Küçük yaşlarda kıssa ve atasözlerini kullanma oranı; yaşları 3-6 arasında olanlarda \% 80 oranında ve yaşları 6-9 arasında olanlarda ise bu oran \% 67,03'tür. Bu sonuç, ileri yaşlara oranla 9 yaşından daha küçük çocukların başkalarından kıssaları dinleme eğiliminde olduklarını göstermektedir.

Tablo 3. Kıssa ve Atasözlerini Kullanma Yöntemi ile Çocukların Yaşlarının İlişkisi

\begin{tabular}{lllllll}
\hline Çocuğun Yaşı & Evet & \multicolumn{3}{c}{ Hayır } & \multicolumn{3}{c}{ Toplam } \\
\cline { 2 - 7 } & S & $\%$ & S & $\%$ & S & $\%$ \\
\hline $3-6$ & 40 & 80 & 10 & 20 & 50 & 100 \\
$6-9$ & 61 & 67,03 & 30 & 32,97 & 91 & 100 \\
$9-13$ & 23 & 16,08 & 120 & 83,92 & 143 & 100 \\
$13-15$ & 11 & 10,89 & 90 & 89,11 & 101 & 100 \\
Toplam & 135 & 35,06 & 250 & 64,93 & 385 & 100 \\
\hline
\end{tabular}

İslami bir eğitim yöntemi olarak kıssa ve atasözlerinin kullanılması tercihinin çocukların yaşlarıyla ilişkisi ele alındığında; araştırmaya göre ister peygamber kıssaları olsun isterse de sahabe kıssaları olsun, ebeveynler en çok 6-9 yaşlarındaki çocuklarına kıssa ve atasözü ile eğitimi tercih etmektedirler; en az oran ise 13-15 yaşlarındaki çocuklarda olmuştur. Bunu anne babaların küçük çocuklarıyla daha fazla ilgilendiği şeklinde yorumlayabiliriz.

Cezayirli ailelerde çocuklar, nineleri ve dedelerinin geçmiş zamanlara ilişkin, 
Bu hikâyelerin önemli eğitici bir niteliği söz konusuydu. Maalesef bugün bu alışkanlık, daha doğrusu çocuklara öğüt verme, yönteminin gittikçe azaldığını görüyoruz. Hâlbuki bu alışkanlık, çocukların ebeveynlerindeki güzel davranışları görmelerine ilave olarak sözlü olarak dinleyerek de kıssalardaki güzellikleri içselleştirmelerini sağlamaktaydı.

Anket verilerine göre; anne babası namazı vaktinde kılan çocukların \% 87'si de namazlarını vaktinde kıldıklarını ifade etmişlerdir. Haftada en az üç kez Kuran okuyan çocukların \% 97'sinin anne ve babaları da aynısını yapmaktadırlar. Bu nedenle, bilinçli Cezayirli bir ailenin iyi örnekliğin çocuklarını yetiştirme üzerindeki etkisinin son derece farkında olduğunu görüyoruz. Bunu şu ayetten elde etmektedirler: "Şüphesiz, sizden Allahıa ve ahiret gününe kavuşmayı uman ve Allahı çok ananlar için, Allahın Peygamberinde güzel bir örnek vardır." 17 Gençlerin gönüllerinde güzel etkiler bırakması nedeniyle Hz. Peygamber (sav) bütün müminler için güzel bir örnek olmuştur.

\section{Sonuç}

İslam, çocukların iyi bir şekilde yetiştirilmesine ve onları dinlerine ve toplumlarına faydalı olmaları için uygun şekilde eğitilmelerine özen göstermiştir. Zira Kur'an çocuklara özel ilgi gösterilmesini şöyle dile getirmektedir: "Allah size çocuklarınız konusunda öğütte bulunuyor."18 ve "Ey inananlar! Kendinizi ve ailenizi, yakıtı insanlar ve taşlar olan ateşten koruyun."19

Çocuk, yetişmesini ve terbiyesini üstlenen doğal çevre olan ailede doğar. Çünkü babalık ve annelik içgüdüsü, hem babayı hem de anneyi özellikle erken dönemlerden itibaren çocuğa bakmaya ve korumaya sevk eder. Erken çocukluk evresi, sonraki dönemlerde çocuğun gelişiminin bağlı olduğu temel olması nedeniyle, insanın gelişim sürecindeki en önemli hayat evrelerinden birisidir.

Çocuğun kalbine gerçek bir imanın yerleştirilmesi, Allah'a, var olan sıfatlarıyla gerçekleşecek tam bir inanç, ona gösterilecek sevgi, boyun eğme ve O'ndan korkulması, her durumda sadece O'na sığınılması hem çocuklar hem de aileler için mutluluk kaynağıdır. Özellikle de inanç duyguya, akla, bilime ve hikmete dayalı sağlam eğitim yöntemlerine dayanıyorsa; işte o zaman inanç çocuğun hayatında ahlakın kaynağını oluşturacaktır. 
İslamıın çocukların iyi bir şekilde eğitilmesine ve onların dinlerine ve toplumlarına faydalı olmaları için en uygun biçimde hazırlanmalarına özen gösterdiği açıtır. Kur'an-1 Kerim çocuklara gereken önemin verilmesini istemektedir. Nitekim Yüice Allah şöyle buyurur: "Allah çocuklarınız hakkında size tavsiye (ve emr) eder." 20 "Ey inananlar! Kendinizi ve ailenizi, yakıtı insanlar ve taşlar olan ateşten koruyun." 21

Bu araştırmada özetle şu sonuçlara ulaşılmıştır:

- Cezayirli aileler, çocuklarına din öğretiminde öncelikle İslam'ın inanç esaslarını tercih etmektedirler.

- Cezayirli aileler, çocuklarına din öğretiminde İslam'ın beş şartını öğretmeye gayret etmektedirler.

- Cezayirli aileler, çocuklarına din öğretiminde, Kur'an'dan sure ve duaları öğretmeyi önemsemektedirler.

- Cezayirli aileler, çocuklarına din öğretiminde, Kur'an ezberletmeye okul öncesi dönemde başlamaktadırlar.

- Cezayirli aileler, çocuklarına din öğretiminde, aile içinde teşvik ve sakındırma yöntemini kullanmakta ve Allah sevgisini telkin etmeyi esas almaktadir.

- Cezayirli aileler, çocuklarına din öğretiminde, hikâye ve atasözlerini kullanma yöntemlerini tercih etmektedirler.

- Cezayirli aileler, çocuklarına din öğretiminde, hikâye ve atasözlerini kullanmada kız ve erkek çocuklarına göre farklılıklar vardır.

Yukarıda da ortaya koyduğumuz gibi, dinimizin eğitim ve ahlak yöntemleri, genellik, bütünlük, kapsamlılık, özgünlük, karşılıklı bağımlılık ve uyum ile karakterize edilir ve o aynı zamanda fıtrata ve inanç ilkelerine bağlıdır. $\mathrm{Bu}$ yöntemler Cezayir ailesinde var olan iki temelden; Kur'an-1 Kerim ve $\mathrm{Hz}$. Peygamber'in hayatından kaynaklanır. Cezayirli ailelerin çocuklarını yetiştirme şekli, yaşlarına göre korkutma, yönlendirme ve yol gösterme yöntemine dayanmaktadır. Öte yandan aileler kıssalarla eğitim yöntemini benimsememektedirler. Buradan hareketle, bireylerin sağlıklı bir İslami terbiye ile yetiştirilmesindeki büyük yararları olması nedeniyle, babalara, özellikle de annelere bu yönteme ilişkin öğüt verilmesinin zorunlu olduğuna inaniyoruz.

Çocuk ve Medeniyet 2021/2
20 Nisa, 4/11.

21 Tahrim, 66/6. 


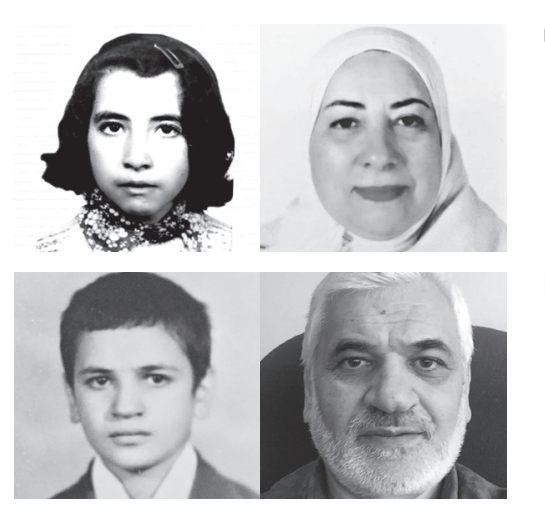

\section{Cevida Emira (Djaouida Amira)}

Mustafa Mücahit

\section{Kaynakça}

Abdülmü'min, I. S. (2004). el Ahlak fi'l-Islam -Nazariyye vet-Tatbik-. Kahire: Mektebetü'r-Rüșd.

Angers, M. (1997). Initiation Pratique àla Méthodologie des Sciences Humaines. Alger: Casbah Université.

Boudon, R. (1970). Les Méthodes en Sociologie. Paris: Presse Universitaire de France.

Cabir, S. M. (1997). et-Tiflu fi's-Seriati'I-Islamiyye ve Menhecü't-Terbiyeti'n-Nebeviyye, Silsiletü'।Kitabi't-Terbevi'I-Isslami. (ed. Münir Sadeddin). Beyrut: el Mektebetü'I-Asriyye, Sayda.

El Acemi, M. A. vd. (2004). Terbiyetü't-Tıfli fi'l-lslam Nazariyye ve't-Tatbik. Riyad: Mektebetü'r Rüșd.

El Beyanuni, A. I. (1985). el Iman Billah. Beyrut.

El Himali, A. A. (1988). Üslubü'I-Bahsi'l-lctimai ve Tekniyyatihi. Bingazi: Menșuratü Camiati Karyunus.

El Kahtani, S. bin A. bin V. (2015). el Ahlak fi' I-Islam. Suudi Arabistan: Mektebetü'I-Melik Fehd.

El Useymin, M. bin S. bin M. (2001). Mekarim'ül-Ahlak. Suudi Arabistan: Daru'I-Vatan.

En Nehlavi, A. (1983). Usulü't-Terbiyeti'l-islamiyye. Dımeșk: Dar'ul-Fikr.

Es Sallabi, A. M. (2011). el İman Billah. Beyrut: Daru'I-Marife.

Ez Zintati, A. es S. (1993). Üsüsü't-Terbiyeti'l-İslamiyye fi's-Sünneti'n-Nebeviyye. Tunus: Eddaru'I-Arabi Lil Kitab.

Grawitz, M. (1993). Menahic'ül-Ulumi'l-lctimaiyye. (çev.: S. Ammar). Dımessk: el Munazzamatü'l Arabiyye li't-Terbiyeti ve's-Sekafeti ve'I-Ulum.

Hilmi, M. (2004). el Ahlak Beyne'I-Felasife ve Ulemai'I-Isslam. Beyrut: Darü'I-Kutubi'I-IIImiyye.

İbni Teymiyye. (1993). Kitab'ul İman. Kahire: Darü'I-Kutubi'I-Imiyye.

İbni Teymiyye. (t.y.). Mecmu'ul-Feteva. Suudi Arabistan: Darư'I-Alemi'l-Kitab.

Kutub, M. (2001). Rekaiz'ül-Iman. Kahire: Dar'us Suruk.

Talas, M. E. (2012). et Terbiyetü ve't-Talim fi' I-Islam. Kahire: Müessetü'I Hindavi li' t-Talim ve's-Sekafe. Ulvan, A. N. (t.y.). Terbiyetü'I Evlad fi'l-İslam. Kahire: Dar's Selam Li’t-Tabaati ve'n-Neșr. 